\title{
Клінічний випадок синдрому Бадда - Кіарі в хірургічній практиці
}

\begin{abstract}
Мета роботи: наведено рідкісний випадок синдрому Бадда - Кіарі в хірургічній практиці, його ускладнення та труднощі діагностики.

При ретроспективному аналізі хвороби запідозрити у пацієнтки наявність синдрому Бадда - Кіарі можливо було лише при детальному зборі анамнезу захворювання, ретельному клінічному нагляді за перебігом хвороби з використанням комплексу лабораторних методів дослідження та сучасної діагностичної техніки. Це дає можливість своєчасно розпізнати і встановити до операції правильний діагноз: синдром Бадда - Кіарі. Незважаючи на проведену автопсію істинного етіологічного фактора виникнення синдрому Бадда - Кіарі встановити не вдалося.
\end{abstract}

Ключові слова: синдром Бадда - Кіарі; асцит; венозний тромбоз брижових вен; перитоніт; хірургічне лікування.

Прийнято розрізняти хворобу Кіарі та синдром Бадда - Kiapi [1, 4-7].

Синдром Бадда - Kiарі - симптомокомплекс захворювання, що характеризується наявністю повного або часткового блока печінкових вен на підгрунті їхнього первинного тромбозу або облітеруючого ендофлебіту з порушенням венозного відтоку з печінки та явищами портальної гіпертензії, асцитом, печінковою недостатністю. Це захворювання вперше описали Ламброан (Lambroan, 1842), Бадд (Budd, 1846). Як самостійну форму захворювання вперше виділив та вивчив празький патологоанатом Г. Kiapi (H. Chiari, 1899). Синдром Бадда - Kiapi - досить рідкісне захворювання без чіткої клінічної картини [4, 5,7 ].

Захворювання зустрічається частіше у пацієнтів віком від 2040 років; однаково уражає як чоловіків, так і жінок, а також у ранньому дитячому віці та у новонароджених. Однак етіологія його остаточно не встановлена. Більш вірогідна поліетіологічна природа захворювання [2, 4, 5, 8]. Частина авторів вважає первинним запалення стінок печінкових вен (ендофлебіт) - інфекційно-токсичний початок, що особливо очевидно у новонароджених - перехід флебіту пупкової вени по аранцієвому протоку на печінкові вени. Деякі автори висувають припущення про головну роль механічного ушкодження печінкових вен поблизу їх впадання в нижню порожнисту вену, зокрема, при сильних кашльових поштовхах, напруженні, травмі живота. Ряд авторів вказує на можливу роль вад розвитку печінкових судин, які призводять до порушення зв'язку печінкових вен із нижньою по- рожнистою веною, а також про значення підвищеного згортання крові на тлі істинної поліцитемії $[7,8]$.

Тромбози та склероз стінок печінкових вен частіше виникає у місці їх впадання до нижньої порожнистої вени, а звідси переходять на дрібні внутрішньопечінкові, ворітну, селезінкову та брижові вени. Хворі помирають від розвитку печінкової недостатності або внаслідок гострого венозного тромбозу брижових вен, ускладненого геморагічним некрозом кишечника та перитонітом [1, 5, 7].

Труднощі діагностики синдрому Бадда - Kiapi загальновідомі. Прижиттєво даний синдром майже не встановлюється. У більшості випадків виявляють під час проведення операційних втручань або під час патологоанатомічного розтину. Диференціювати синдром Бадда - Кіарі необхідно перш за все з істинним цирозом печінки [5, 7].

Розрізняють гостру та хронічну форми синдрому Бадда - Kiapi. У випадках гострого перебігу захворювання розвивається бурхливо, виникає біль у животі, швидко накопичується асцитна рідина, яка не зникає від сечогінних препаратів; печінка збільшується, стає болючою, розвивається печінкова кома. Летальність при цьому може настати впродовж одного-чотирьох тижнів від початку захворювання [1, 5, 7].

При хронічній формі перебігу хвороби спостерігаються жовтяниця, асцит, гепатомегалія, печінкова недостатність. Смертельний наслідок захворювання настає впродовж півроку. Інколи хворі при повільному перебігу захворювання можуть жити декілька років $[1,5]$. 
Лікування хвороби Кіарі та синдрому Бадда Кіарі спричиняє значні труднощі. Фібринолітична та антикоагулянтна терапія дають неоднозначні результати. На сьогодні перспективні в лікуванні синдрому Бадда - Кіарі різні ендоваскулярні втручання $[3,7,10]$.

Мета роботи: необхідність узагальнити та проаналізувати особливості клінічного перебігу, труднощі діагностики та лікування ускладненого синдрому Бадда - Kiapi, який ми спостерігали.

Впродовж 2016-2019 рр. у центрі із лікування шлунково-кишкових кровотеч КНП “Криворізька міська лікарня № 16” КМР проліковано 471 хворого 3 цирозом печінки, ускладненим портальною гіпертензією, асцитом, шлунково-кишковою кровотечею з варикозно-розширених вен стравоходу та кардіального відділу шлунка. Синдром Бадда Kiарі трапився лише у одному випадку захворювання, що склало 0,2 \% відносно всіх пролікованих хворих.

Пацієнтка К., 58 років захворіла у червні 2019 р., коли з'явилися загальна слабість, помірний біль та відчуття тяжкості в правому підребер'ї, збільшення живота. Захворювання ні з чим не пов'язує. Анамнез життя без особливостей: туберкульоз, вірусні гепатити, венеричні захворювання, алергії, травматичні пошкодження живота заперечувала. Впродовж місяця проходила лікування в терапевтичному відділенні однієї з лікарень міста. Встановлено клінічний діагноз: цироз печінки нез'ясованої етіології субкомпенсований, портальна гіпертензія III ст., варикозне розширення вен стравоходу I ст., поліпоз шлунка, асцит. Проводили сучасне цілеспрямоване консервативне лікування. У лабораторних дослідженнях спостерігали лейкоцитоз із зсувом вліво лейкоформули до мієлоцитів, епізодичне підвищення глюкози крові до 9 ммоль/л. Пігментний обмін без особливостей, спостерігали збільшення креатиніну, сечовини, амілази, а також АЛТ та АСТ. Маркери вірусних гепатитів В та С були негативні. В системі гемостазу все було в межах референтних показників. (Гематологічні, загальноклінічні та біохімічні лабораторні показники консультовані на кафедрі клінічної лабораторної діагностики факультету післядипломної освіти Дніпровської державної медичної академії.)

Після проведеного цілеспрямованого лікування стан хворої покращився. У відділенні перед виписуванням проведено СКТ органів грудної клітки та черевної порожнини з підсиленням. Висновок: відсутня візуалізація печінкових вен. Картина може відповідати синдрому Бадда - Kiapi? Цироз печінки, портальна гіпертензія, асцит, правобічний ексудативний плеврит. Хвору виписали з від- ділення за власним бажанням із рекомендацією подальшого лікування в гастроентерологічному відділенні.

Через тиждень після виписування з терапевтичного відділення планово 27.08.2019 р. була госпіталізована до гастроентерологічного відділення 16-ї лікарні зі скаргами на помірний біль по всьому животі ниючого характеру, відчуття тяжкості більше у правому підребер'ї, збільшення живота в об’ємі. Діагноз при госпіталізації у відділення був сформульований згідно з випискою 3 історії хвороби пацієнтки: цироз печінки нез'ясованої етіології, стадія декомпенсації, ПФПК ІІ ст., асцит, правобічний гідроторакс, хронічний панкреатит.

Призначено лікування згідно з клінічним протоколом при даному захворюванні. При пункції правої плевральної порожнини отримано 1,5 л транссудаду світло-солом'яного кольору без запаху. При мікроскопічному дослідженні плевральної рідини - атипових клітин не виявлено, значна кількість еритроцитів та лейкоцитів. При абдоміноцентезі отримано 4 л асцитичної рідини, атипових клітин не виявлено. При мікроскопії осаду виявлено багато еритроцитів, лейкоцити, що густо покривають поле зору, переважно нейтрофіли.

Незважаючи на проведене лікування, біль у животі різноманітного характеру продовжував наростати. Через 2 тижні після госпіталізації до гастроентерології з підозрою на гострий панкреатит, гостру кишкову непрохідність, ішемічний абдомінальний синдром хвору перевели до хірургічного відділення. Проведений пасаж барієвої суміші по кишечнику, контрастна маса пройшла з уповільненням через 40 годин. Кишкова непрохідність, гострий панкреатит були виключені.

Незважаючи на подальше застосування загальноприйнятої терапії стан хворої погіршувався, зростала загальна слабість, посилилися тупі ниючі болі в правому підребір'ї. Після проведеного лапароцентезу відбулося швидке наростання асцитичної рідини. Хвора помітно схудла. Температура тіла залишалася нормальною, навіть не спостерігався субфебрилітет за весь період хвороби.

Із допоміжних методів обстеження було проведене УЗД органів черевної порожнини, при якому виникла підозра на гепатоцелюлярний рак печінки, асцит [5, 9].

Для визначення подальшої лікувально-діагностичної тактики 20.09.2019 р. відбувся розширений авторитетний консиліум за участю докторів медичних наук, професорів кафедр хірургії та терапії. Встановлено діагноз: гепатоцелюлярний рак?, цироз печінки в стадії декомпенсації, портальна гіпертензія, асцит-перитоніт. Правобічний 
гідроторакс. СПОН. Гепаторенальний синдром, дефіцит маси тіла. Рекомендовано перевести до палати інтенсивної терапії анестезіологічного відділення для стабілізації стану з подальшим проведенням діагностичної лапаротомії.

В анестезіологічному відділенні проводили інтенсивну терапію відповідно до необхідних призначень. 23.09.2019 р. стан хворої різко погіршився, виникло наростання больового синдрому в животі з чіткими симптомами подразнення очеревини. Діагностовано перитоніт нез'ясованого генезу. За життєвими показаннями 23.09.2019 р. під загальним знеболенням проведено серединну лапаротомію. При розтині черевної порожнини виявлено розлитий серозно-фібринозний перитоніт, випоту до 2-2,5 л, геморагічний сегментарний некроз клубової кишки на протязі 12 см на відстані 70 см від ілеоцекального кута. Крім того, виражений набряк та синюшність брижі тонкої кишки, венозне повнокров’я висхідного та низхідного відділів ободової кишки, заочеревинного простору. Ділянка інфаркту кишки представлена у формі характерного трикутника, який основою прилягав до кишки. Печінка щільна, дрібнозерниста, коричневого кольору. Селезінка помірно збільшена. Проведено резекцію некротизованого відрізка тонкої кишки 3 міжкишковим анастомозом “бік-у-бік”. При проведенні мобілізації брижі спостерігали видавлювання венозних тромбів із вен брижі. Операцію завершено санацією та дренуванням черевної порожнини.

\section{СПИСОК ЛІТЕРАТУРИ}

1. Большая медицинская энциклопедия. - Москва : Издательство “Советская энциклопедия”, 1979. - Т. 10. - С. 289-292.

2. Крикунова А. Р. Клинический случай: Синдром Бадда-Киари на фоне генетически детерминированной формы тромбофилии / А. Р. Крикунова, В. Д. Кузнецов, В. А. Ткачева // Синергия наук. - 2018. - № 24 - С.1235-1242.

3. Мужаровский А. Л. Эндоваскулярные вмешательства в лечении осложнений синдрома портальной гипертензии : дисс. ... кандидата медицинских наук : 14.01.17. - хирургия. - Санкт-Петербург, 2017 - 166 с.

4. Кузин М. И. Хирурургические болезни / М. И. Кузин. Москва : “Медгиз”, 2002. - С. 562-573.

5. Неотложная гастроэнтерология / Крылов А. А., Земляной А. Г., Михайлович В. А., Иванов А. И. - Ленинград : “Медицина”, 1988. - 264 с.

6. Петрух Любов Українсько-латинсько-англійський медичний словник / Любов Петрух, Ірина Головко. - Київ : ВСВ “Медицина”, 2015 - 968 с.
Незважаючи на проведення реанімаційних заходів із застосуванням тромболітичної, фібринолітичної, антикоагулянтної, детоксикаційної, гепатотропої та антибактеріальної терапії, при наростанні інтоксикації, печінково-ниркової, серцево-легеневої недостатності хвора померла 26.09.2019 р., провівши у лікарні 30 ліжко-днів. Загальна тривалість захворювання становила 2,5 місяця.

Встановлено клінічний діагноз: а) основний: гострий синдром Бадда - Kiapi; б) ускладнення: цироз печінки декомпенсований. ПФПК III ст. Портальна гіпертензія, асцит, тромбоз вен брижі тонкого кишечника. Сегментарний геморагічний некроз тонкої кишки. Розлитий серозно-фібринозний перитоніт. Інтоксикація. СПОН; в) супутній діагноз: IXC: кардіосклероз атеросклеротичний. Поліпоз шлунка.

Патологоанатомічний діагноз збігся з клінічним.

При ретроспективному аналізі хвороби запідозрити у пацієнтки наявність синдрому Бадда - Кіарі було можливо лише при детальному збоpi анамнезу захворювання, ретельному клінічному спостереженні за перебігом хвороби з використанням комплексу лабораторних методів дослідження, сучасної діагностичної техніки, які дають можливість своєчасно розпізнати та встановити до операції правильний діагноз.

Незважаючи на проведену автопсію істинного етіологічного фактора синдрому Бадда - Kiapi встановити не вдалося.

7. Redefining Budd-Chiari syndrome: a systemic review / N. Shin, Y. H. Kim, H. Xu [et al.] // World J. Hepatol. - 2016. Vol. 8 (16). - P. 691-702. DOI: 10.4254/wjh.v8.i16/69/

8. The relationship between the levels and function of endothelial progenitor cells and factor $\mathrm{V}$ Leiden and protein $\mathrm{C}$ deficiency in patients with primary Budd-Chiari syndrome / Z. U. Guan, C. W. Yu, T. Song, Y. Gao // Eur. Rev Med. Pharmacol. Sci. - 2018. - Vol. 22 (9). - P. 2742-2750. DOI: 10.26355/ eurrev_201805_14971.

9. Characteristics of hepatocellular carcinoma in Egyptian patients with primary Budd-Chiari syndrome / M. Sakr, S. M. Abdelhakam, H. Dabbous [et al.] // Liver Int. - 2017. Vol. 37 (3). - P. 415-422. DOI:10.1111/liv.13219.

10. Khan F. Timing of transjugular intrahepatic portosystemic stentshunt in Budd-Ciari syndrome: A UK Hepatologist's Perspective / F. Khan, H. Mehrzad, D. Tripathi // J. Transl. Int. Med. - 2018. - Vol. 6 (3). - P. 97-104. DOI: 10.2478/ jtim-2018-0022. 


\title{
КЛІНІЧНИЙ ВИПАДОК
}

\section{REFERENCES}

1. (1979). Bolshaya meditsinskaya entsiklopediya [Great medical encyclopedia]. Moscow: Sovetskaya Entsyklopediya [in Russian]. 2. Krykunova, A.R., Kuznecov, V.D., \& Tkacheva, V.A. (2018). Klinicheskiy sluchay: Sindrom Badda-Kiari na fone geneticheski determinirovannoy formy trombofilii. Sinergia nauk [Clinical case: Badd's-Kiary syndrome compliating genetic determinated form of thrombophilia]. Sinergia nauk - Synergy of Science, 24, 1235-1242 [in Russian].

3. Muzharovskiy, A.L. (2017). Endovaskuliarnye vmeshatelstva v lechenii oslozhneniy syndroma portalnoy gipertenzii [Endovascular interventions in the treatment of complications of portal hypertension syndrome]. Candidate's thesis. St.Petersburg [in Russian]. 4. Kuzin, M.I. (2002). Khirurgicheskie bolezni [Surgical diseases]. Moscow: Medgiz [in Russian].

5. Krylov, A.A., Zemlianoy, A.G., Myhaylovich, V.A., \& Ivanov, A.I. (1988). Neotlozhnaya gastroenterologiya [Emergencies in gastroenterology]. Leningrad: Meditsina [in Russian].

6. Petruh, L., \& Golovko, I. (2015). Ukrainsko-latynsko-anhliiskyi medychniy slovnyk [Ukrainian-Latin-English medical vo- cabulary]. Kyiv: VSV Medytsyna [in Ukrainian]. 7. Shin, N., Kim, Y.H., Xu, H., Shi, H.B., Zhang, Q.-Q., Colon Pons, J.B., ... Li, L-S. (2016). Redefining Budd-Chiari syndrome: a systemic review. World J. Hepatol., 8 (16), 691-702. DOI: 10.4254/wjh.v8.i16/69.

8. Guan, Z.U., Yu, C.W., Song, T., \& Gao, Y. (2018). The relationship between the levels and function of endothelial progenitor cells and factor V Leiden and protein C deficiency in patients with primary Budd-Chiari syndrome. Eur. Rev. Med. Pharmacol. Sci., 22(9), 2742-2750. DOI: 10.26355/eurrev_201805_ 14971. 9. Sakr, M., Abdelhakam, S.M., Dabbous, H., Hamed, A., Hefny, Z., Abdelmoaty, W., ... Eldorry, A. (2017). Characteristics of hepatocellular carcinoma in Egyptian patients with primary Budd-Chiari syndrome. Liver Int., 37 (3), 415-422. DOI:10.1111/ liv.13219.

10. Khan, F., Mehrzad, H., Tripathi, D. (2018). Timing of transjugular intrahepatic portosystemic stentshunt in Budd-Ciari syndrome: A UK Hepatologist`s Perspective. J. Transl. Int. Med., 6 (3), 97-104. DOI: 10.2478/jtim-2018-0022.

\section{A. KOVTONYUK ${ }^{1}$, V. A. SAVENKO ${ }^{1}$, E. F. SAMARETS ${ }^{2}$, V. M. LUKYIANENKO ${ }^{1}$, S. O. FEDYUSHKIN¹, T. I. YELCHANINOVA ${ }^{3}$}

Kryvyi Rih City Hospital No. $16^{1}$

Kamianske Medical College of Dnipropetrovsk Regional Council ${ }^{2}$

Dnipro Medical Academy ${ }^{3}$

\section{CLINICAL CASE OF BUDD-CHIARI SYNDROME IN SURGICAL PRACTICE}

\begin{abstract}
The aim of the work: the article describes a rare case of Budd-Chiari syndrome in surgical practice, its complications and diagnostic difficulties. The presence of Budd-Chiari syndrome is possible to diagnose only with detailed history taking, meticulously clinical examination while disease is going with employing up-to-date instrumental and laboratory diagnostic complexes. Worth mentioning that correct diagnostics of Budd-Chiari syndrome before surgery is possible due to comprehensive approach. Unfortunately, but despite the autopsy the genuine etiological factor of the syndrome is not found.
\end{abstract}

Key words: Budd-Chiari syndrome; ascites; mesenteric venous thrombosis; peritonitis; surgical treatment.

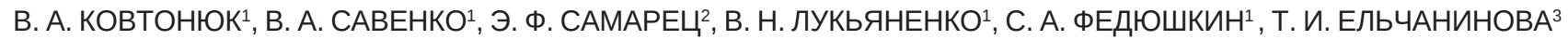

КНП "Криворожская городская больница № 16" КГС ${ }^{1}$

Каменский медицинский колледж ДОС²

Днепровская медицинская академия ФПО

\section{КЛИНИЧЕСКИЙ С.УЧАЙ СИНДРОМА БАДДА - КИАРИ В ХИРУРГИЧЕСКОЙ ПРАКТИКЕ}

\begin{abstract}
Цель работы: описан редкий случай синдрома Бадда - Киари в хирургической практике, его осложнения и трудности диагностики.

При ретроспективном анализе заболевания заподозрить у пациентки наличие синдрома Бадда - Киари возможно было лишь при детальном сборе анамнеза заболевания, тщательном клиническом наблюдении с использованием современной диагностической техники. Это дает возможность своевременно распознать и поставить до операции правильный диагноз: синдром Бадда - Киари. Несмотря на проведенную аутопсию истинного этиологического фактора возникновения синдрома Бадда - Киари установить не удалось.
\end{abstract}

Ключевые слова: синдром Бадда - Киари; асцит; венозный тромбоз брыжеечных вен; перитонит; хирургическое лечение. 